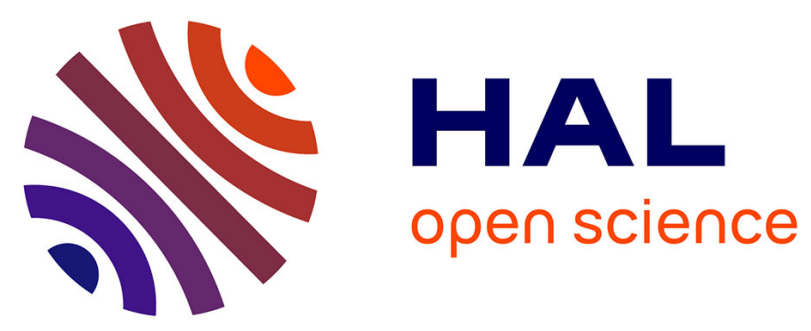

\title{
The new Algerian locality of Bir el Ater 3: validity of Libycosaurus algeriensis (Mammalia, Hippopotamoidea) and the age of the Nementcha Formation
}

Fabrice Lihoreau, Lionel Hautier, Mohammed Mahboubi

\section{- To cite this version:}

Fabrice Lihoreau, Lionel Hautier, Mohammed Mahboubi. The new Algerian locality of Bir el Ater 3: validity of Libycosaurus algeriensis (Mammalia, Hippopotamoidea) and the age of the Nementcha Formation. Palaeovertebrata, 2015, 39-2, pp.e1. 10.18563/pv.39.2.e1 . hal-01893840

\author{
HAL Id: hal-01893840 \\ https://hal.science/hal-01893840
}

Submitted on 12 Oct 2018

HAL is a multi-disciplinary open access archive for the deposit and dissemination of scientific research documents, whether they are published or not. The documents may come from teaching and research institutions in France or abroad, or from public or private research centers.
L'archive ouverte pluridisciplinaire HAL, est destinée au dépôt et à la diffusion de documents scientifiques de niveau recherche, publiés ou non, émanant des établissements d'enseignement et de recherche français ou étrangers, des laboratoires publics ou privés. 


\title{
The new Algerian locality of Bir el Ater 3: validity of Libycosaurus algeriensis (Mammalia, Hippopotamoidea) and the age of the Nementcha Formation
}

\author{
FABRice LIHOREAU ${ }^{\text {a* }}$, LIONEL HAUTIER ${ }^{\text {a }}$ \& MOHAMmed MAHBOUBI ${ }^{b}$ \\ ${ }^{a}$ Institut des Sciences de l'Evolution, Université de Montpellier, CNRS, IRD, EPHE, CC 064, Place Eugène Bataillon 34095 \\ Montpellier cedex 05, France \\ ${ }^{b}$ Laboratoire de Paléontologie Stratigraphique et Paléoenvironnement, Université d'Oran 2, BP 1524 Oran El M'naouer, 31000 , \\ Algérie \\ * Corresponding author: fabrice.lihoreau@univ-montp2.fr
}

\begin{abstract}
The description of original material of anthracothere and proboscidean in the new locality of Bir el Ater 3 from East Algeria, and a thorough review of early Libycosaurus remains of Bir el Ater 2 allows us validating L. algeriensis as the smallest and earliest species of Libycosaurus and probably the earliest migrant of the genus from Asia. The presence of a Tetralophodon in the Neogene Nementcha formation might represent the earliest occurrence of the genus in Africa. These original fossil remains allow us to discuss the age of the Neogene part of the Nementcha formation close to the Serravalian/Tortonian boundary.
\end{abstract}

Keywords: Dispersal event, Miocene, North Africa, Tetralophodon

Submitted 27 April 2015, Accepted 1 June 2015

(C) Copyright Fabrice Lihoreau June 2015

\section{INTRODUCTION}

The transition between middle and late Miocene in North Africa is scarcely recorded and faunal transitions are largely unknown in this part of the world and for this time interval (see review in Werdelin, 2010). In that context, the fossil collection established from Bled Douarah in the Beglia formation, central Tunisia (Robinson and Black, 1974) is key to understand African faunal evolution and dispersion prior to the setting of the arid Saharan barrier (Douady et al., 2003; Griffin, 2002; Lihoreau et al., 2006).

Discoveries of new localities from this time interval are critical. We describe here new Miocene fossils from the locality of Bir el Ater 3 in the Nementcha formation (East Algeria). Bir el Ater is renowned for its Late Eocene locality (e.g., Coiffait et al., 1984; Bonis de et al., 1988) but this area also yielded Miocene mammalian remains in Bir el Ater 2 (Ducrocq et al., 2001; Mahboubi et al., 2003). The Nementcha formation in Bir el Ater can be considered either as a probable western extension of the Beglia formation, or as an earlier sedimentary phase, when considered the general progradation of the fluvio-lacustrine series toward the East in this part of the Maghreb (Mannaï-Tayech \& Otero, 2005). The anthracothere species from Bir el Ater 2, Libycosaurus algeriensis Ducrocq et al., 2001 was first described as a basal representative of the genus (Ducrocq et al., 2001; Lihoreau et al., 2014). However, the validity of this species has then been challenged due to the low number of associated remains and the lack of clear diagnostic characters observable (e.g. Pickford, 2006). We present here original material from a new Miocene locality near Bir el Ater 2 that completes the description of L. algeriensis and provides evidence of the presence of a tetralophodontine proboscidean. It allows us discussing the age of the basalmost part of the Nementcha formation and proposing an evolutionary history scenario for the Libycosaurus lineage, which involves a dispersal event of anthracothere from Asia toward Africa during the Middle Miocene (Lihoreau et al., 2006).

\section{GEOLOGICAL CONTEXT AND MATERIAL}

The original fossil materials have been unearthed in 1987 by one of us (MM) in a lenticular bed located on the right bank of the Oued Halail River, on the southern side of the Nementcha mounts, $60 \mathrm{~km}$ west from the city of Bir el Ater. The new locality is close to Bir el Ater 2, about one kilometer north on the same river bank, and about four kilometers west of the Eocene Bir el Ater locality (Fig. 1). Part of this new material was evoked in a previous work on the Neogene from Bir el Ater 2 (Ducrocq et al., 2001) and in a review of stratigraphical context of the area (Mahboubi et al., 2003). The undescribed remains belong to a Neogene sedimentary series that can reach $1000 \mathrm{~m}$ in thickness in this area (Mahboubi et al., 2003). These fossils were found about $250 \mathrm{~m}$ stratigraphically lower than Bir el Ater 2 and $150 \mathrm{~m}$ above Bir el Ater (Eocene continental, Fig. 1). Due to stratigraphical and geographical differences, we have decided to name the new locality Bir el Ater 3. It corresponds to the closest fossiliferous level to the Eocene/ Miocene contact in this area. The Miocene is represented by fluvial to fluvio-deltaic weakly agglutinated sandstones with alternation of red silts and gritstones. This Miocene continental series can be compared to the well-described Beglia formation in Tunisia (see Mannaï-Tayech, 2009) but lithographical correlations are difficult due to the presence of heterogeneous facies in the latter (Mannaï-Tayech, 2006). Considering that the continental series of the Beglia formation is supposed to be progradant toward Northeast, the Algerian localities might represent the lowest known fossiliferous locality of this formation. Biochronological correlation with Bled Douarah (in the Beglia $\mathrm{fm}$ ) was proposed on the ground of the presence of Libycosaurus and the Nementcha formation was hypothesized to be late Middle to early late Miocene (Ducrocq et al., 2001). However, the age of the Beglia formation is poorly constrained (Serravalian and early Tortonian; Werdelin, 2010), the Bled Douarah locality in particular, which is supposed to be close to middle-late Miocene boundary (near 11.63 Ma following 
Hilgens et al., 2012). Difference in Libycosaurus species attribution (Ducrocq et al., 2001) would rather support heterochrony between the two localities.

\section{SYSTEMATIC PALEONTOLOGY}

CETARTIODACTYLA Montgelard, Catzeflis \& Douzery, 1997

CETANCODONTA Arnason et al., 2000

HIPPOPOTAMOIDEA Gray, 1821 (sensu Gentry \& Hooker, 1988)

ANTHRACOTHERIIDAE sensu Leidy, 1869

BOTHRIODONTINAE Scott, 1940

Libycosaurus Bonarelli, 1947

Type species. Libycosaurus petrocchii Bonarelli, 1947

Included species. Libycosaurus petrocchii from Libya (restricted to the type considered as lost; see Lihoreau et al., 2014), L. anisae (Black, 1972) from Tunisia and possibly Uganda, L. bahri Lihoreau et al. 2014 from Libya and Chad, L. algeriensis Ducrocq et al. 2001 from Algeria.

Range and distribution. Late middle Miocene (11 Ma) to late Miocene (7 Ma) in Africa.

Libycosaurus algeriensis Ducrocq et al. 2001 (Figs 2-4)

Holotype. Fragmentary maxilla with left M2/-M3/ (UONM1)

Paratypes. Twelve tooth fragments (see Ducrocq et al., 2001 for list)
New material. A left fragment of mandible with complete $\mathrm{m} / 2-\mathrm{m} / 3$ from the Algerian locality of Bir el Ater 3 (UONM-14). This material is housed at the University of Oran 2, Algeria.

Type Locality. Bir el Ater 2, Nementcha, Algeria

Type horizon. Nementcha formation, considered to be late Serravalian.

Emended diagnosis. Smallest known species of the genus; retention of a small endometacristid on lower molars that connects preprotocristid; ectocristylids that form cusplets in the transverse valleys near a developed labial cingulid; only one postentostylid on the posthypocristulid separated with hypoconulid apex by a lingual groove. Enamel microstructure of molars retains large and blurry Hunter Schreger Bands. Shallow mandible with a weak vascular impression. Retention of a lingual cingulum around protocone in upper molars even in worn specimen.

Differential diagnosis. Libycosaurus algeriensis differs from other species of Libycosaurus by its smaller dimensions with shallow mandible, the presence a small endometacristid on lower molars, the ectocristylids always developed in cusplets in the transverse valleys, which is rare in other species, the large lingual cingulum around protocone of upper molar even in worn specimens. It also differs from $L$. anisae by the presence of only one entostylid on the third lobe of the $M / 3$. It differs from $L$. bahri by the presence of a posthypocristulid on $\mathrm{M} / 3$, a weak vascular impression on mandible and by large and blurry Hunter Schreger Bands on enamel.

\section{Comparative description}

Teeth. The teeth description follows the dental nomenclature established for Hippopotamoidea (Boisserie et al., 2010;

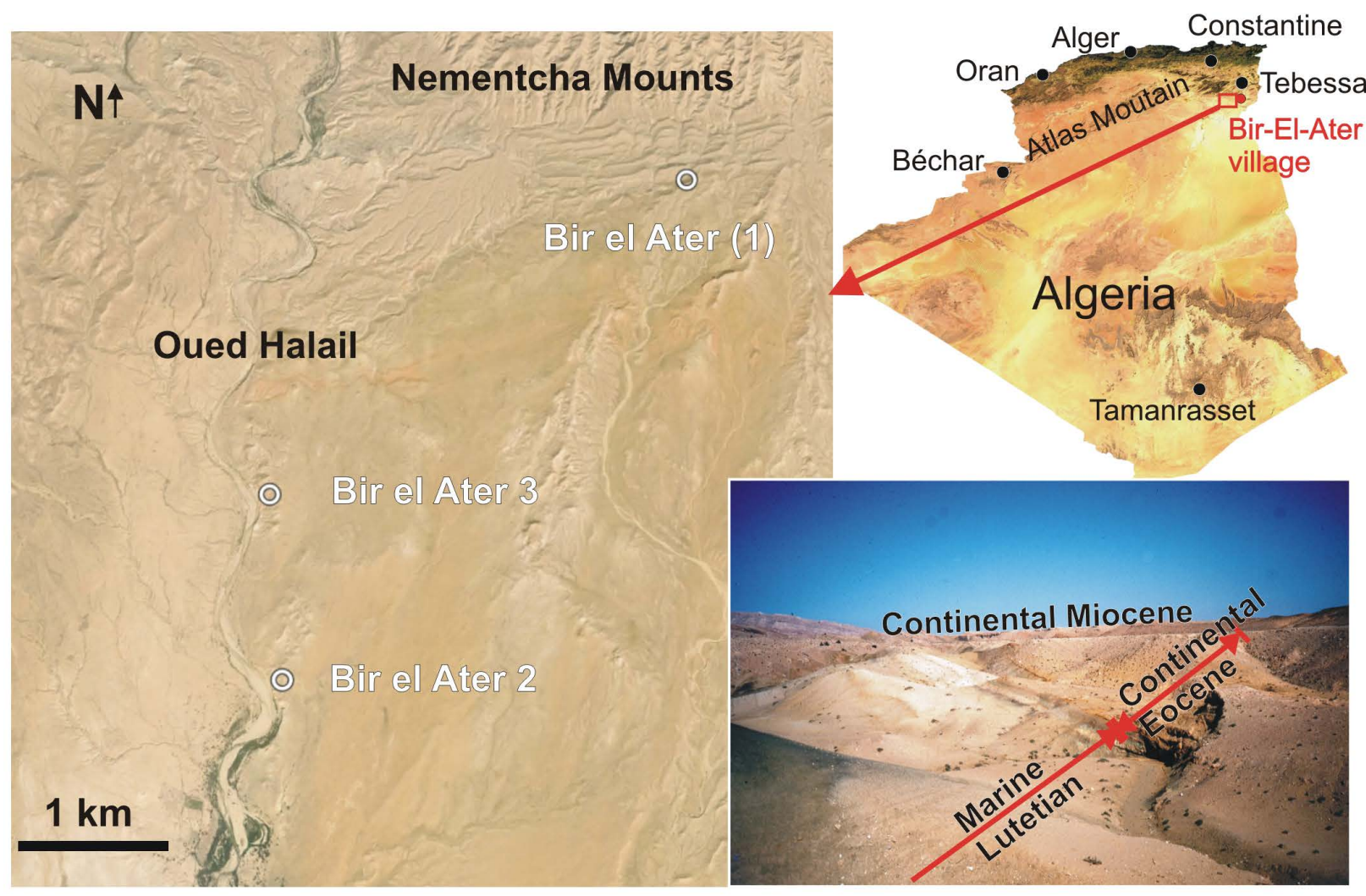

Figure 1. Geographic position of the fossiliferous localities of Bir el Ater (Eocene -(1), and Miocene -2) in Algeria, with the localisation of the new locality, Bir el Ater 3. On the right lower corner the photograph of the Eocene-Miocene unconformity near the locality of Bir el Ater (1). 
Fig. 3). The lower molars present the characteristic features of bothriodontines (see Lihoreau \& Ducrocq, 2007; Figs. 2-3) including the long development of prehypocristid that reaches the lingual margin of the tooth. The presence of a strong labial cingulid, considered as diagnostic for the species L. algeriensis (Ducrocq et al., 2001), is also observed in other Libycosaurus and Merycopotamus species. It is slightly developed in Sivameryx but never enlarged in front of labial cuspids in other bothriodontines.

The lower molars from Bir el Ater 3 (Fig. 2C) present char- acteristic features of the genus Libycosaurus such as the lack of premetacristid, the presence of a small postentocristid wedged between the base of the entoconid and the posthypocristid (also known in derived Merycopotamus species; Lihoreau et al., 2007), a labial loop-like hypoconulid with a notch (incomplete posthypocristulid displaying at least one accessory cuspid), and the presence of an ectoentocristid. This morphology differs from the genera described in the African Miocene Brachyodus, Sivameryx (Fig. 3) and Afromeryx.

The lower molars differ from L. anisae and L. bahri by the
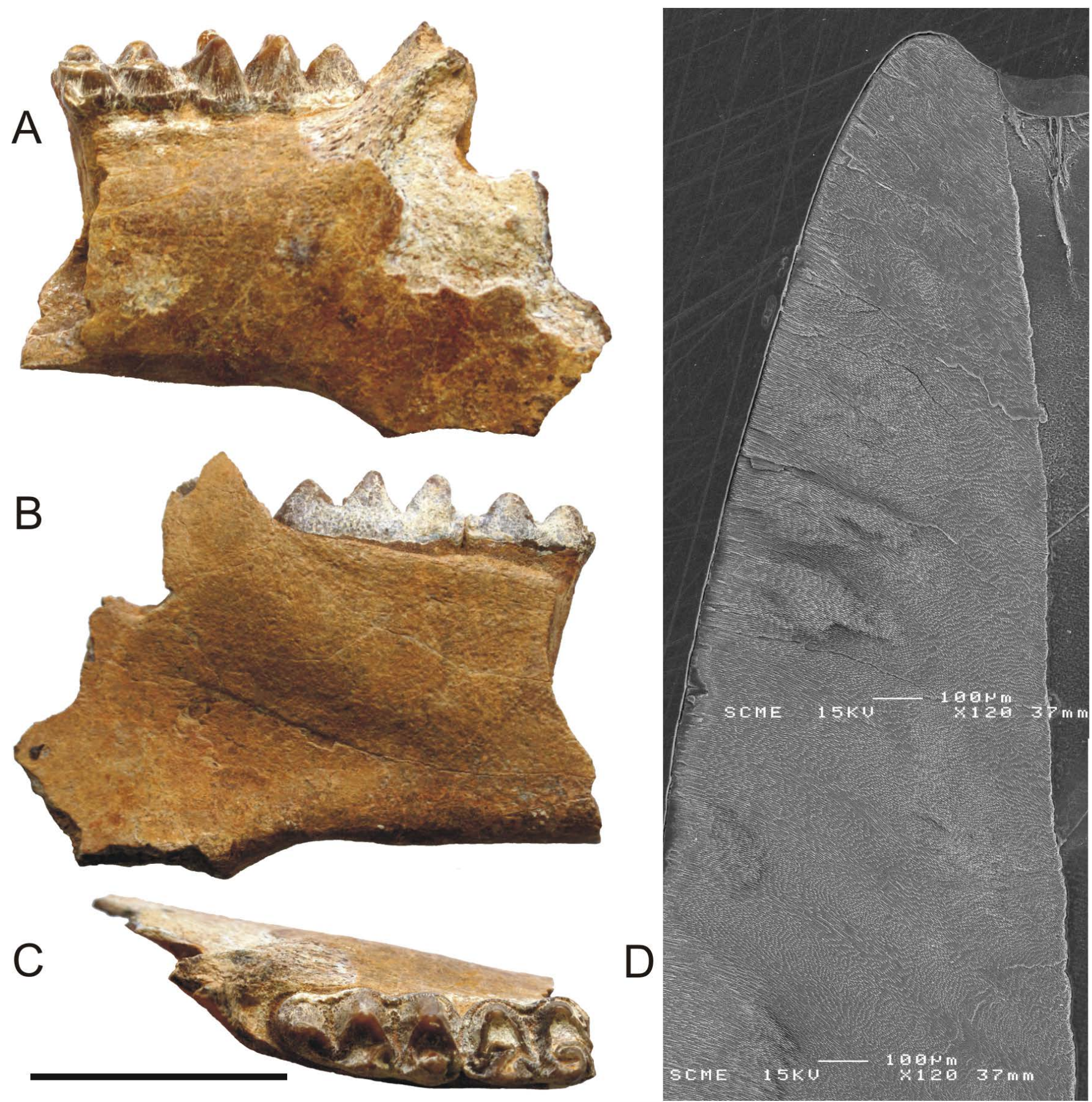

Figure 2. Libycosaurus algeriensis from Nementcha Formation, Algeria. A-C, (UONM-14) left hemi-mandibular fragment with $\mathrm{m} / 2$-m/3 of $L$. algeriensis from Bir el Ater 3. A, labial view. B, lingual view. C, occlusal view. D, SEM picture of a vertical section of enamel of a molar of $L$. algeriensis from Bir el Ater 2. Scale bar equals $5 \mathrm{~cm}$. 
retention of a small endometacristid that connects preprotocristid (Figs. 2-3). The labial cingulid is adorned with ectostylids, which reinforces the idea of a large cingulid (see Ducrocq et al., 2001).

There are cusplets in the transverse valleys of lower molars considered as ectocristilids also present in the four known specimens of L. algeriensis. Ectocristilids in L. anisae and $L$. bahri do not form cusplets but a succession of small tubercles in line and when cusplets can be observed in these species the frequencies are of $0 \%$ in L. anisae $(\mathrm{n}=23)$ and $2.5 \%$ in L. bahri $(n=40)$.

A postentostylid is present on the third lobe of the $M / 3$ and is separated by a distal groove with the hypoconulid apex in all known specimens of $L$. algeriensis $(\mathrm{n}=4)$. In L. anisae, the condition differs by the presence of many stylids of equivalent size (in 13 specimens among 14) and the lack of clear groove that separates the entostylid from the rest of the posthypocristulid (Fig. 3). In L. bahri, the posthypocristulid lacks and thus the stylid remains only on the cingulid. Lingual cuspids of lower molar are more linguo-labially flattened whereas they present a rounded outline in occlusal view in other Libycosaurus species. This is probably due to more sharpened cristids in L. algeriensis than in the other species. This condition also exists in early Merycopotamus species.

The lower molars of the new specimen are always shorter mesio-distally $(\mathrm{m} / 2=25.7 \mathrm{~mm} ; \mathrm{m} / 3=35.9 \mathrm{~mm})$ and linguo-labially $(\mathrm{m} / 2=17.1 \mathrm{~mm} ; \mathrm{m} / 3=16.8 \mathrm{~mm})$ than $L$. anisae specimens, but they are very similar in size to L. algeriensis (Fig. 4). When comparing the mean length and breadth of $\mathrm{m} / 3$, we found differences between the group including L. algeriensis and Bir el Ater 3 specimen $(36.2 \mathrm{~mm} / 17.6 \mathrm{~mm})$ and the group including the specimens from loc17 of Bled Douarah $(44.2 \mathrm{~mm}$ / $23.9 \mathrm{~mm}$ ), the upper level of Bled Douarah (44.4 mm / 23.6 $\mathrm{mm}$ ), the Djebel Krechem el Artsouma (40.5 mm / $21 \mathrm{~mm}$ ), Sahabi $(58.8 \mathrm{~mm} / 25.7 \mathrm{~mm})$, and Toros-Menalla $(59.1 \mathrm{~mm}$ $130.8 \mathrm{~mm}$ ). Unfortunately, there are too few known specimens of L. algeriensis to apply a t-test on these measurements. In contrast, there is no mean difference between Bled Douarah localities, between Bled Douarah and Djebel Krechem, and between Sahabi and Toros-Menalla.

Enamel microstructure. Alloing-Séguier et al. (2014) described in detail the enamel microstructure of L. algeriensis. We further compare here the previous analysis of enamel from Bir el Ater 2, Libycosaurus bahri, and Merycopotamus spp. On the vertical section, enamel is $856 \mu \mathrm{m}$ thick on the metacone quite similar to $M$. nanus and $M$. medioximus but much smaller than in L. bahri $(1330 \mu \mathrm{m})$. The Schmelzmuster presents three zones (Fig. 2D) with the presence of Hunter Schreger Bands (HSB; $47 \%$ of the whole thickness). In more recent Libycosaurus species, HSB are absent whereas they are slightly larger in M. medioximus and M. nanus. Indeed, the Inner Radial Enamel is more developed in Bir el Ater 2 specimen than in Merycopotamus species. Hunter Schreger Bands in $L$. algeriensis can be larger than $100 \mu \mathrm{m}$ and only M. nanus and $M$. medioximus show such large bands among anthracotheres (Alloing-Séguier et al., 2014). The low decussation angle of prisms between two HSB and the large transition zone between bands (several prisms correspond to intermediate decussating states between the two HSB) in Bir el Ater 2 specimen (Fig. 2) differ from Merycopotamus. However the Algerian enamel also displays blurry HSB which is a characteristic feature of Merycopotamus. Interrowsheet are present in the inner part of the enamel thickness as in M. medioximus and L. bahri and unlike $M$. nanus that only presents them in the middle part.

In regard of all the characteristics of enamel microstructure, we can notice that L. algeriensis (the specimen from Bir el Ater 2) differs from $L$. bahri and reminds M. medioximus. However, the large development of the inner radial enamel in $L$. algeriensis can be considered as transitional between $M$. medioximus and L. bahri. Unfortunately, no data exists for the enamel of $L$. anisae and M. dissimilis.

Mandible. The mandible is shallow (depth below $\mathrm{m} / 3=54.5$ mm; Figs. 2, 4). Lihoreau et al. (2014) demonstrated that the mandibular depth in L. bahri can vary markedly with the age

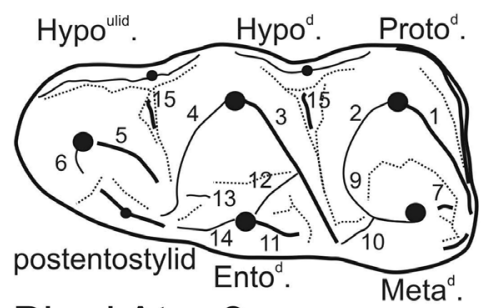

Bir el Ater 3

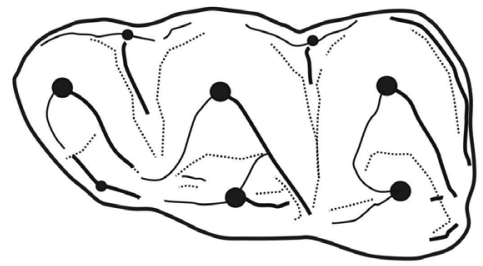

L. algeriensis

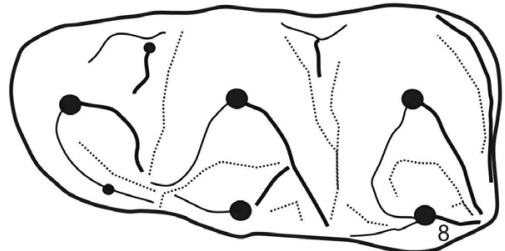

M. medioximus

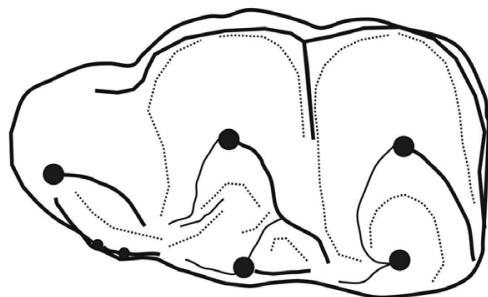

L. anisae

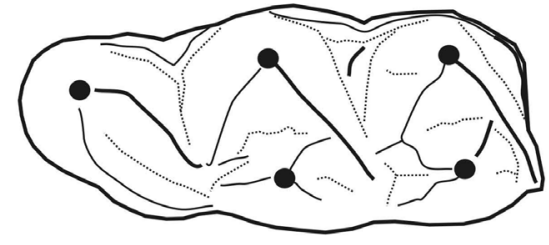

S. africanus

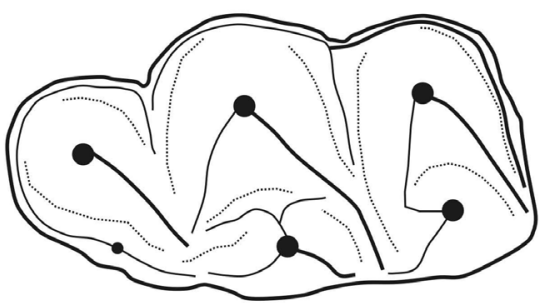

L. bahri

Figure 3. Comparisons of occlusal pattern of third left lower molar from Bir el Ater 3 (UONM-14) with five bothriodontine species. All specimens scaled at same length and oriented with mesial part of the tooth rightward and lingual part downward. Proto ${ }^{\mathrm{d}} .:$ protoconid; Meta $^{\mathrm{d}} .:$ metaconid; Hypo ${ }^{\mathrm{d}} .:$ hypoconid; Ento ${ }^{\mathrm{d}} .:$ entoconid; Hypo $^{\text {ulid }}$ :hypoconulid; 1: preprotocristid; 2: postprotocristid; 3: prehypocristid; 4: posthypocristid; 5: prehypocristulid; 6: posthypocristulid; 7: endometacristid; 8: premetacristid; 9: postmetacristid; 10: postectometacristid; 11: ectoentocristid; 12: preentocristid; 13: postentocristid; 14: postectoentocristid; 15: ectocristylids. 
and with the sex. Compared with adult specimens (age class of 5-8) of L. anisae (mean of $74.8 \mathrm{~mm}$ with values comprised between 64.8-82.9 $\mathrm{mm}$ ) and adult specimens of L. bahri (mean of $117 \mathrm{~mm}$ with values comprised between 78.1-146.4 mm), the specimen from Bir el Ater 3 is always shallower than $L$. anisae, regardless of sex attribution. The mandibular height is more consistent with measurements taken on Merycopotamus specimens (mean of $45.7 \mathrm{~mm}$ for $M$. nanus and of $55.5 \mathrm{~mm}$ for M. medioximus; Lihoreau et al., 2004).

The ventral border of the mandible below $M / 3$ is straight in specimens from Sahabi and TM, but a vascular impression is noticeable in some L. anisae specimens (e.g., T3528) as well as in Merycopotamus (Lihoreau et al., 2007) and earlier bothriodontine species. In UONM-14, the slight mandibular vascular impression together with the small size are supposed to be a plesiomorphic condition for Libycosaurus (Lihoreau et al., 2014; Fig. 2).

PROBOSCIDEA Illiger, 1811

ELEPHANTIFORMES Tassy, 1988

ELEPHANTOIDEA Gray, 1821

GOMPHOTHERIIDAE Hay, 1922

TETRALOPHODONTINAE van der Maarel, 1932

Tetralophodon Falconer, 1857.

Type species. Tetralophodon longirostris (Kaup, 1832)

Included species. Tetralophodon longirostris (Kaup, 1832) from Austria, Germany, Georgia, Moldova, Spain, Turkey, Ukraine and possibly in Tunisia (Bergounioux \& Crouzel, 1956); T. punjabiensis (Lydekker, 1886) from Pakistan; T. xiaohensis Qi et al. 2006 from China; T. xiaolongtanensis (Chow \& Chang, 1974) from China.

Other possible included species. T. falconeri (Lydekker, 1877) from India (see Shoshani \& Tassy, 1996: 363); T. buzdarensis Sarwar, 1977 from Pakistan; T. exoletus Hopwood, 1935 from China (possible synonymy with $T$. xiaolongtanensis, see Tobien et al., 1988); T. hasnotensis (Osborn, 1929) from Pakistan and China (considered as a Paratetralophodon by Tassy (1983) but attributed to Tetralophodon following Tobien et al. (1988))

Range and distribution. Late Miocene and early Pliocene of Europe, Asia, Africa.

Diagnosis. Based in part on Coppens et al. (1978), Sanders et al. (2010), and Tobien et al. (1988). Large gomphotheriid genus with tetralophodont intermediate molars (i.e. with four completely developed loph(id)s together with an individualised strong talon(id)) and third molars with five-six loph(id) s. Symphysis deflected, under reduction but not as short as that in the Anancinae. Lower incisors small relatively to molar sizes, likewise reduced, mostly separated without contact at their tips. Upper incisors without enamel band, slightly curved downward and/or outward. Second-fourth permanent premolars are retained; upper and lower tooth formulae 1-0-3-3, 1-0-2-3, respectively. Occasional development of secondary trefoils on posttrite half-loph(id)s. Differs from anancine gomphotheres in straighter transverse alignment of the half-loph(id)s. Enamel massively thick.

\section{Tetralophodon sp.}

Material. left D/4 UONM-15, a right P4/ UONM-16 and a right $\mathrm{M} / 2$ UONM-17 (Figs 5-6). This material is housed at the University of Oran 2, Algeria.

\section{Comparative description}

Deciduous lower premolar. The left $\mathrm{D} / 4$ is brachyodont and tetralophodont (Fig. 5A-B). All the lophids are functional but the fourth posttrite half-lophid is not worn. The first lophid is largely broken. The decidual tooth was more than $76 \mathrm{~mm}$ long and the maximum widths of the second and third lophids are 42 and $43.5 \mathrm{~mm}$ respectively. The enamel is rugose, folded, and crenulated; it is $3 \mathrm{~mm}$ thick. Each half-lophid is composed of two main cuspids with the mesoconelets and principal tubercles being of similar size (Fig. 5A). There is no alternation of the half-lophids. The crown structure is very simplified with no accessory conule on the posttrite side, instead small anterior and posterior swelling crests prefigure a trefoil pattern. A central pretrite conule (acprc) is clearly individualized on

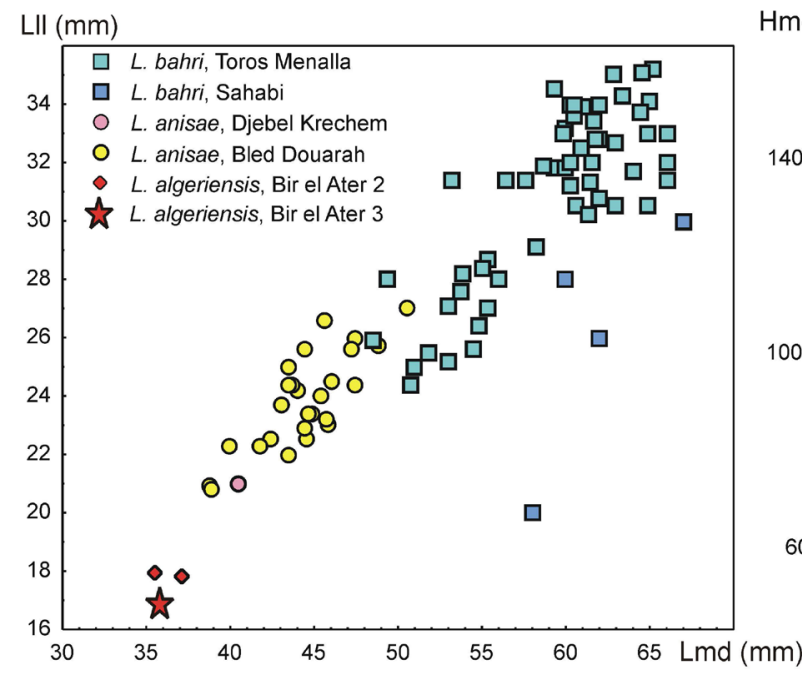

Hmd (mm)

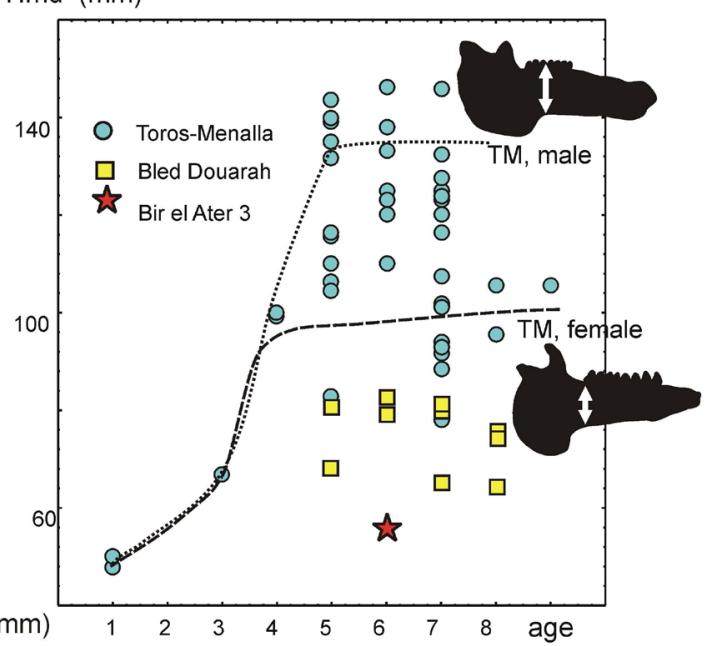

Figure 4. Biometric comparisons of anthracothere specimen UONM-14 from Bir el Ater 3. Left, distribution on bivariate graph of the m/3 measurements compared with species of Libycosaurus (measurements from Lihoreau et al. 2014). Right, comparison of mandibular depth below posteriormost erupted tooth for each age class of Libycosaurus species (measurements from Lihoreau et al. 2014). 
the first lophid; it is more bulge-like on the lophid 2 and 3 and barely detectable on the fourth one. Posterior central pretrite conules (pcprc) are present on the first three lophids; they correspond to swellings that are not completely distinct from the mesoconelet. No clear contact is established between the pcprc and the acpre of the following lophid. A marked median sulcus is visible between each half lophids. In a worn state, the pretrite half-lophids form incomplete trefoil patterns, which only partially block the interlophid valleys. The last lophid is really simple. The last posttrite half-lophid is monocuspid, and so is the posterior cingulum.

Decidual teeth have been recovered for African nonanancine tetralophodont groups in Libya (Sahabi; Gaziry, 1987) and in Kenya (Nakali, Saegusa et al., 2014; Samburu Hills, Nakaya et al., 1984; Tugen Hills, Tassy, 1986). The specimen can be clearly differentiated from a D/4 of Stegotetrabelodon (Gaziry, 1987) in that the latter has more plate-like anterior lophids with wide interlophid valleys noticeably filled with cementum, as well as a fully developed fourth lophid where the two halves are angling backwards. All Libyan D/4 are also significantly larger with a crown measuring between $95 \mathrm{~mm}$ and $100 \mathrm{~mm}$ in length. The morphology of the Algerian $\mathrm{D} / 4$ is overall quite similar to the D4/ described in Ngorora (fig. 11, plate 9: Tassy, 1986) both in size and morphology. It is always delicate to compare lower teeth with upper ones but similar trends are observable between the D4/ from Ngorora and the Algerian D/4 regarding the complexity of the crown, the weak expression of the pretrite and posttrite accessory conules and the narrowness of the fourth loph(id).

Lower premolar. The right $\mathrm{P} / 4$ is brachyodont and bilophodont (Fig. 5C-D). It is barely worn. The premolar is slightly longer $(\mathrm{L}=53.4 \mathrm{~mm})$ than wide $(11=35.67 \mathrm{~mm} ; 12=29.82 \mathrm{~mm})$ and roughly rectangular in shape. The enamel thickness is $3 \mathrm{~mm}$ at the cervix on the second lophid. Each lophid is composed of two main cusps and incipient pretrite mesoconelets (Fig. 5C). A pcprc is present on each lophid whereas an acprc is present only on the first one. There is no clear contact between the pcprc1 and the acprc2, which are set apart by a marked transverse fold. The crown is longitudinally divided by a median sulcus separating pretrite and posttrite sides. The anterior cingulid is tetracuspid with two reduced lateral cuspids. No surface contact is visible anterior to it, so the presence of a $\mathrm{P} / 3$ (a characteristic of Miocene gomphotheres; Tassy, 1986) can be questioned. The posterior cingulid is bicuspid; a contact surface is present. No cementum is visible on the crown.

The most complete lower premolars of African nonanancine tetralophodont gomphotheres are known from Nakali (Kenya; Saegusa et al., 2014), Samburu Hills (Kenya; Nakaya et al., 1984), Tugen Hills (Kenya; Tassy, 1986), and Djebel Krechem (Tunisia; Geraads, 1989). The Algerian P/4 resembles the one of Tetralophodon longirostris in showing a cprp1 (Saegusa et al., 2014). Fourth premolars of Stegotetrabelodon clearly differ from the latter in displaying cementum and no accessory conule in the first interlophid, they also display broadened second half-lophids with 3 pretrite and posttrite tubercles (fig. 8, plate 9 in Tassy, 1986). No P/4 is known from the Samburu Hills (Nakaya et al., 1984, 1987) and the Tugen Hills (Kenya; Tassy, 1986). The overall morphology of a worn left $\mathrm{P} / 3$ of a tetralophodont form from Ngorora (fig. 10, plate 9 in Tassy, 1986) is similar to the Algerian $\mathrm{P} / 4$ but it is smaller $(\mathrm{L}=42.5 \mathrm{~mm})$. Both teeth are characterized by the presence of marked median sulcus and incipient pepre1 and acprc2 in the interlophid. However, no posterior cingulum is distinguishable on the Kenyan third premolar. The right $\mathrm{P} / 4$ from the Nakali formation (Saegusa et al., 2014) is wholly worn; it is similar in shape to the Algerian $\mathrm{P} / 4$ but differs from the latter in size (the Kenyan premolar
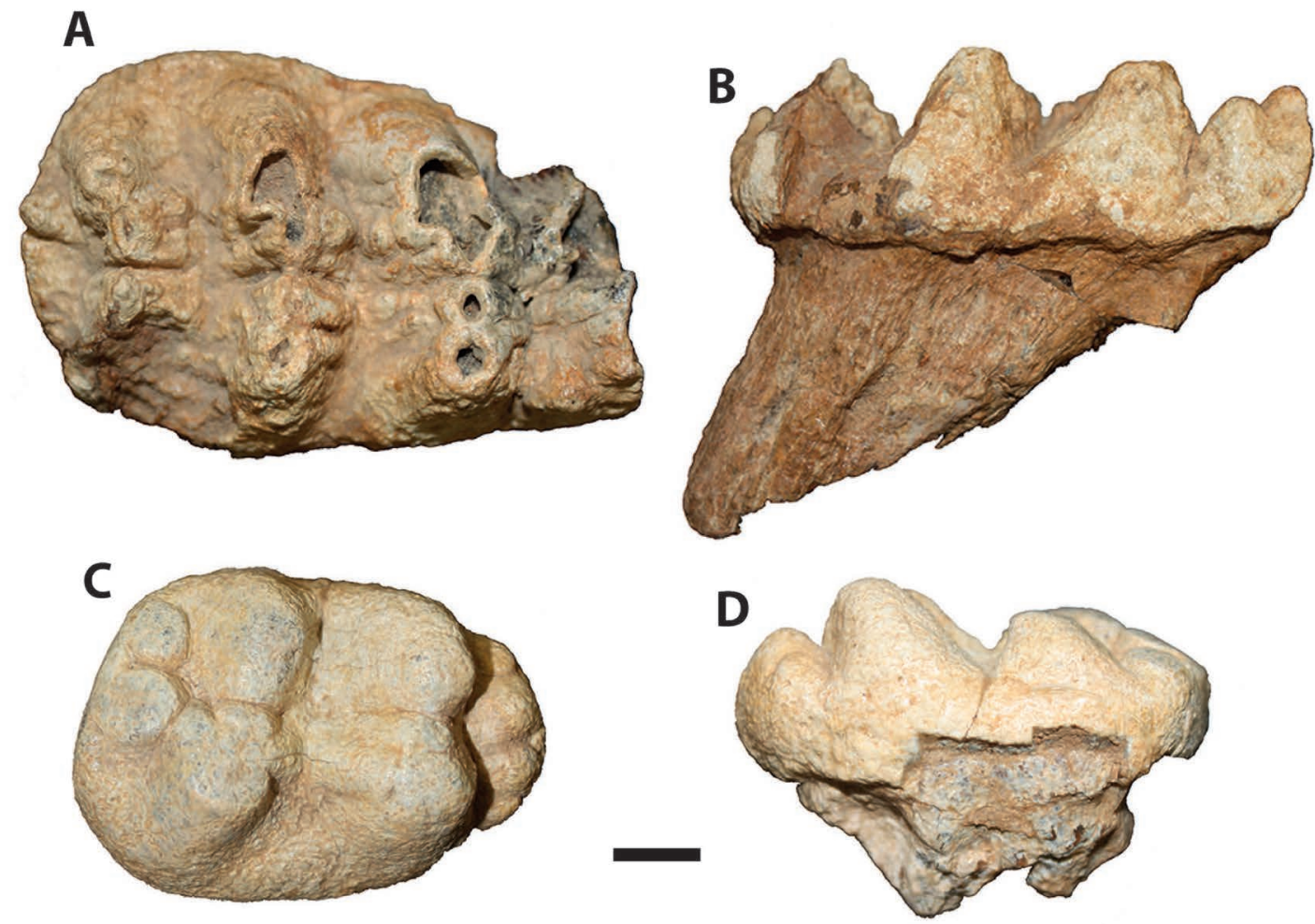

Figure 5. Tetralophodon remains from Bir el Ater 3. A-B UONM-15 left D/4. A, Occlusal view. B, lingual view. C-D UONM-16 right P/4. C, Occlusal view. D, lingual view. Scale bar equals $1 \mathrm{~cm}$. 
being smaller) as well as in the complete absence of accessory conule, the lesser development of the anterior cingulum, and a putative presence of cementum (not specified but see fig. 1B in Saegusa et al., 2014). Geraads (1989) described a P/4 from Djebel Krechem similar in size to the P/4 of Bir el Ater 3. However, the morphology of the Algerian premolar contrasts with the Tunisian one, which shows a strong central conule in the interlophid as well as a second lophid much wider than the first one (Geraads, 1989).

Lower molar. The right worn $\mathrm{M} / 2$ is brachyodont and tetralophodont (Fig. 6). The enamel is massively thick (between 6 and $10 \mathrm{~mm}$ ). Even partially broken, the molar appears large at its fourth lophid $(14=68 \mathrm{~mm})$ compared to its length $(\mathrm{L}=147 \mathrm{~mm})$. Lamellar frequency is low (between 2.5 and 3). The dislocation of the half-lophids is slight to absent. The crown structure is complex on the proximal side and simple on the distal side, with mesoconelets competing in size with the main conelets (Fig. 6A). The three first pretrite half-lophids are largely broken mesially. The mesoconelets of the first three lophids are accompanied with extended bulge-like anterior and posterior central pretrite conule (acprc and pcprc) that gives a trefoil shape to the half-lophids. A contact is established between the pcprc and the acprc of the following lophid, which blocks the valleys (Fig. 6A). The fourth half-lophid is simplified with the lack of pcprc and a mesoconelet largely jointed to the principal tubercle. On the posttrite side, the crown structure is slightly different. The anterior half-lophids are simpler with no anterior and posterior central posttrite conule (acpoc and pcpoc). The mesoconelets, weakly separated from principal tubercles by folds, are rounded. The last posttrite mesoconelet is slightly compressed buccolingually. The tubercles do not converge to
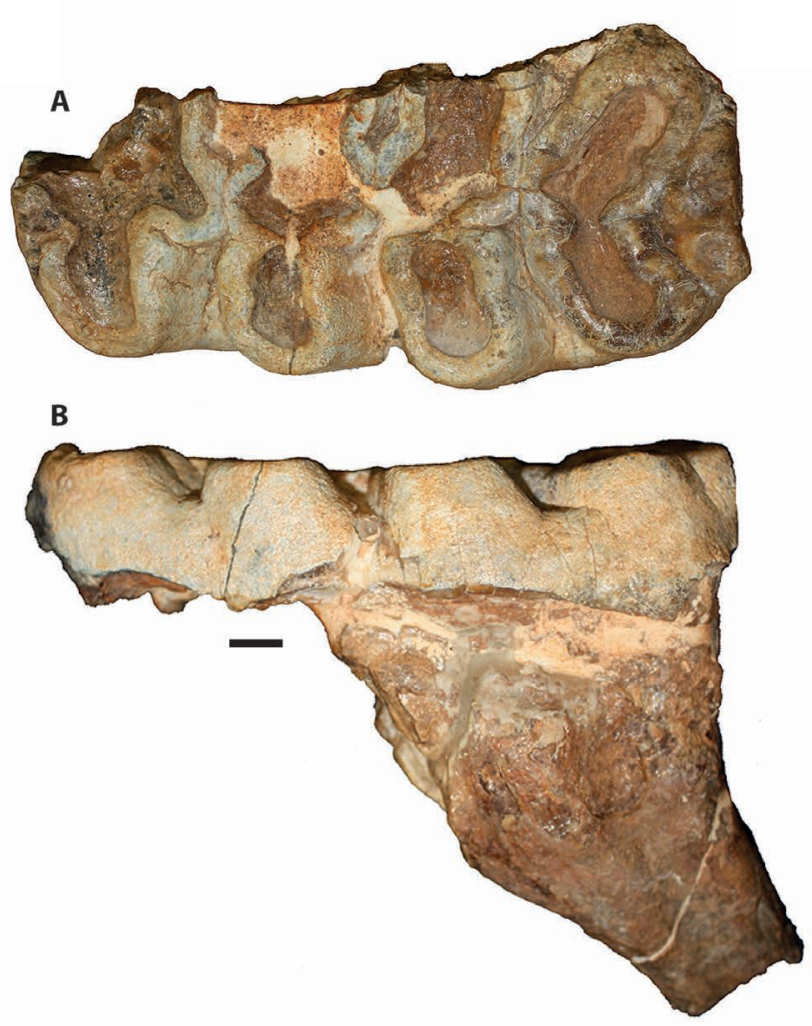

Figure 6. Tetralophodon remains from Bir el Ater 3. A-B UONM-17 right M/2 A, Occlusal view. B, lingual view. Scale bar equals $1 \mathrm{~cm}$. the sagittal plane. The distal cingulum is simple and formed of three rounded tubercles; it does not prefigure a fifth lophid. The tooth probably had two roots, but only the rear one is preserved (Fig. 6B).

Molars of nonanancine tetralophodonts are more commonly found than premolars or decidual teeth. An attribution to $T$. falconeri, T. buzdarensis, and T hastonenis can be ruled out since all these species show molars with a thick cement cover (Tobien et al., 1988). Only one left M3/ is known for T. punjabiensis (Tobien et al., 1988), which precludes any comparison with the Algerian specimen. The Bir el Ater 3 specimen is close morphologically to the molars of T. longirostris and T. xiaolongtanensis, which are characterized by a lack of cement and an absence of posttrite accessory conules. It differs from the type specimen of T. longirostris (Vallesian of Eppelsheim, Tobien, 1978: Plate 10) that is characterized by a fully developed and individualized posterior cingulid. However, this feature is likely to vary intraspecifically since the posterior cingulid remains reduced on a $\mathrm{M} / 2$ of $T$. longirostris from the Vallesian of Esselborn (Tobien, 1978: Plate 14). Both the Bir el Ater 3 $\mathrm{M} / 2$ and the intermediate molars of $T$. longirostris differ from T. xiaolongtanensis that shows a $\mathrm{M} / 2$ with reduced posterior cingulid and fourth posttrite lophid (Dong, 1987).

Molars were described in a number of African Miocene deposits: Nakali formation (Kenya; Saegusa et al., 2014), Samburu Hills (Kenya; Nakaya et al., 1984, 1987), Tugen Hills (Kenya; Tassy, 1986), Lukeino formation (Kenya; Pickford, 1978), Lothagam (Kenya; Tassy, 2003), Wembere-Manonga (Tanzania; Sanders, 1997), Chorora formation (Ethiopia; Geraads et al., 2002; Tiercelin et al., 1979), Sahabi (Libya; Gaziry, 1987), Kakara formation (Uganda; Tassy, 1994), Lake Mobutu Sese Seko (Congo; Madden, 1977), Djebel Krechem (Tunisia; Geraads, 1989), Chérichera (Tunisia; Bergounioux \& Crouzel, 1956). However, second lower molars were rarely found and were only described in the Samburu Hills (Nakaya et al., 1984). The overall morphology of the Algerian $\mathrm{M} / 2$ recalls Tetralophodon molars regarding the low crown, the number of lophids, the low lamellar frequency, the small number of cones forming the lophids, the enlargement of the mesoconelets, the presence of anterior and posterior pretrite accessory conules, the trefoil pattern of the anterior lophids, the persistence of marked median sulcus, and the absence of cementum (Sanders et al., 2010; Tassy, 1994; Tobien, 1978). However, the material is too fragmentary to warrant a specific distinction. The combination of morphological features allows us to reject an assignment to Stegotetrabelodon due to the small number of lophids (M2 plate formula is $\mathrm{x} 5-\mathrm{x} 5 \mathrm{x}$ in Stegotetrabelodon), the absence of strong and individualized median posterior columns (pcprc) between each plate, the absence of deep V-shaped valleys between pyramidal plates in lateral view, the uneven wear of the pretrite and posttrite half lophids, and the absence of cementum (Gaziry, 1987; Sanders, 1997; Sanders et al., 2010; Tassy, 1994). An allocation of the Algerian M/2 to Choerolophodon can also be discarded since the lophids are not arranged in chevrons (Sanders, 2010; Tassy, 1986; Tsujikawa, 2005). The M3/ (KI 64'92) from the Kakara formation, referred to as primitive Elephantidae (Tassy, 1994), differs from the present $\mathrm{M} / 2$ in showing more derived traits of Elephantidae such as cones slightly compressed antero-posteriorly, a reduction of the median sulcus, a lesser development of accessory conules (especially the absence acprc), an even wear of the half lophs, and the presence of cementum. Tassy (1994) considered this molar as very similar to the tetralophodont molars from the Samburu Hills, described as Tetralophodon sp. (Nakaya et 
al., 1984), but he refrained from giving a generic assignment. Sanders et al. (2010) recently argued in favour of the inclusion of this material inside the genus Tetralophodon. If the Kenyan molars do show some morphological similarities with the M3/ (KI 64'92), they differ from it by the complete lack of cementum and the development of secondary trefoils (Nakaya et al., 1984). Unlike the Algerian molar, the Samburu teeth display more plate-like loph(id) and secondary trefoil patterns; they are also significantly bigger (i.e. $>175 \mathrm{~mm}$ ). Tassy (1986) viewed the evolutionary level of these Ugandan (Kakara) and Kenyan (Samburu Hills) molars as more derived than the M/1 recovered in the Mobutu Sese Seko region (Madden, 1977) and more derived than the tetralophodont gomphotheres from the Ngorora formation. Unfortunately, no molar is known in the Ngorora material, which precludes any comparison with the Algerian molar. The Congolese M/1 from Mobutu Sese Seko is largely broken and worn but it does not show elephantid features such as plate-like tendency of the lophids (Madden, 1977; Tassy, 1994). It also wholly lacks cementum, and though resembles the Algerian $\mathrm{M} / 2$ in that way, but it can be differentiated from the latter by the presence of $\mathrm{V}$-shaped valleys and triangular plates in sagittal section. This specimen was first recognized as Tetralophodon sp. (Madden, 1977), but Madden (1982) changed his first identification to refer the molar to as Stegotetrabelodon grandincisivum. More material will be needed to warrant this generic attribution. The same holds true for the material from the Nakali formation (Saegusa et al., 2014), which has so far yielded only fragments of molars. A M/3 (AL1000-1) from the Chorora formation has been referred to as putative Stegotetrabelodon tooth and was considered as a good intermediate between the tetralophodont forms from the Samburu Hills (i.e. Tetralophodon sp.; Nakaya et al., 1984) and the ones from the Kakara formation (i.e. primitive Elephantidae indet.; Tassy, 1994). This molar indisputably shows derived features compared to the Algerian $\mathrm{M} / 2$ including a lesser development of accessory conules (with the absence of all acprc but the first one), and more plate-like lophids coated with cementum. The morphology of the Algerian $\mathrm{M} / 2$ is overall very similar to the $\mathrm{M} 2 /$ of Tetralophodon cf. longirostris described in Djebel Krechem (Geraads, 1989), both in size and morphology. Both molars are characterized by a low crown, four loph(id)s with a fully developed fourth loph(id) where the two halves are angling backwards and a distinct cingulum formed of three rounded tubercles, a low lamellar frequency, a trefoil pattern of the anterior pretrite half loph(id)s associated with more simple posterior loph(id)s, enlarged mesoconelets, a persistence of marked median sulcus, and an absence of cementum. However the Tunisian M2/ distinctly shows a pcpoc on its third loph. From North Africa again, Bergounioux \& Crouzel (1956) also reported the presence of T. longirostris in the Miocene deposits of the Beglia Formation. Compared to the Bir el Ater 3 specimen, the crown structure of the pretrite portion of $\mathrm{M} / 3$ from Chérichera appears simpler with a lesser development of the accessory conules but this material is really fragmentary.

\section{DISCUSSION}

Validity of the species $L$. algeriensis and origin of the genus. Considering the hypodigm of $L$. algeriensis (Ducrocq et al., 2001), Pickford (2006) proposed that "the case for a separate species is weak" even if he discussed the small size of its $\mathrm{m} / 3$ compared to $L$. anisae. The problem of validity of $L$. algeriensis is linked to the scarcity of the material, the few discriminant morphological characters on teeth, and our lack of knowledge on the size variability in Libycosaurus species. Indeed, on the original material from Bir el Ater 2, Ducrocq et al. (2001) mainly identified continuous character state for the species diagnosis such as the global size, the development of cingulum/id on molars, and the compression of lower molar cuspids, likely to show interspecific overlap. Indeed, in order to confirm the discriminant quality of these characters, we need to investigate their variation on a large sample of Libycosaurus species. Pickford (2006) first considered that the creation of this species was premature, but accepted it later based on the recognition of the size variation in L. anisae (Pickford 2009). He considers that the small size of the Algerian remains can fill a gap in an anthracothere lineage displaying a trend to size increase (Pickford, 2009). A rather equivalent conclusion was proposed by Lihoreau et al. (2014) based on teeth size, slender lower molar occlusal shape, and cristid sharpness, which follow the study on size and morphological variability of a large sample of L. bahri.

The new material described in this study confirms the existence of a small Libycosaurus species in Bir el Ater 2 and 3 , which retains a plesiomorphic occlusal pattern (endometacristid, ectocristylids in cusplets, developed labial cingulid on lower molars and lingual cingulum on upper molars, a single entostylid, a posthypocristulid only separated with hypoconulid apex by a lingual groove), a plesiomorphic schmelzmuster on molar enamel, and a shallow mandible with a weak vascular impression.

Lihoreau et al. (2006) proposed an Asian origin for the genus Libycosaurus with potential precursors to be found within the Asian stock of advanced Bothriodontinae (such as Hemimeryx, Sivameryx, and Merycopotamus). It is notably due to the retention of an endometacristid in Libycosaurus, which is also known in Sivameryx and Hemimeryx but lost in Merycopotamus. Another scenario (Lihoreau et al, 2015), still proposing an Asian origin, would be that Libycosaurus derived from a Merycopotamus stock, which implies the paraphyly of the latter genus. Indeed, the latter hypothesis seems supported by numerous morphological resemblances between L. algeriensis and $M$. medioximus, notably the slightly divided mesostyle and the ectocrystilid developed in cusplets. However, more material is needed to propose a well-supported phylogeny of this clade and precise the centre of origin of Libycosaurus.

Age of Bir el Ater 3 and dispersal events. The new proboscidean remains are of primary importance as Sanders et al. (2010) considered that "morphologically and stratigraphically, african tetralophodon is appropriately situated to be ancestral to elephants" and as nonanancine tetralophodonts are poorly represented in the African fossil record. Coppens et al. (1978) mentioned that several North African localities have yielded remains of Tetralophodon longirostris including Zidania and Melka el Ouidane (Morocco); Tozeur, Djebel M'Dilla, Djebel Semene, Sbeitla, Bled Douarah, Chérichera, and Foum el Kranga (Tunisia); and Smandou (Algeria). If this identification has been confirmed in Chérichera and Djebel Semene (Bergounioux \& Crouzel, 1956), Coppens et al. (1978) acknowledged that, in most other cases, the material was too fragmentary to be clearly identifiable and that this identification mostly relied on stratigraphic position rather than morphological features. In fact, the fossil remains from Smendou and Djebel M'Dilla have never been described. The Miocene locality of Tizi N'Tadderht in the Central High Atlas (Morocco, Zouhri et al., 2013) has recently yielded a few fragmentary 
Tetralophodon remains (one mandible with a small part of a badly preserved $\mathrm{M} / 3$ and one half of lophid without accessory conules), which appear to match with the material described from Chérichera.

The combination of morphological characters of the Tetralophodon teeth from Bir el Ater 3 is clearly more primitive than the dental remains of the tetralophodont forms found in Kakara formation (9 Ma; Tassy, 1994), Samburu Hills (9.3 to 9.6 Ma; Nakaya et al., 1984, 1987), and Chorora formation (10.1 to $10.7 \mathrm{Ma}$; Suwa et al., 2007); the dental traits are in return compatible with what is known from Djebel Krechem (10.5-10 Ma; Geraads, 1989) and Ngorora formation (11 Ma; Tassy, 1986). Nevertheless comparisons with the upper molar from Djebel Krechem must be taken with caution as important variation can exists between upper and lower molars of pre-elephantids (Hautier et al., 2009). Assuming that all these tetralophodont forms are closely related and that the intraspecific variation is low, which is rarely the case in gomphotheres, the evolutionary level of the Algerian proboscidean is compatible with an age of Bir el Ater 3 being more or less contemporaneous with the Member D of Ngorora Formation. Considering the early occurrence of the genus in Tunisia, Bergounioux \& Crouzel (1956) suggested an African origin for the group directly from a Gomphotherium stock as proposed by Schlessinger $(1917,1922)$ and Osborn (1936). However, Coppens et al. (1978) and Tobien et al. (1988) considered that Tetralophodon more likely dispersed to Africa from Eurasia where the genus is well represented by several late middle-late Miocene species. The material from Bir el Ater 3 is, for now, too fragmentary to ascertain its specific attribution and more specimens will be needed to bridge the gap between Eurasian and African representatives of the genus.

The presence of a small species of Libycosaurus that does not display the advance character states of $L$. anisae and $L$. bahri supposed an older age than Bled Douarah (and even than the lower level of Bled Douarah, loc. 17). It could not be contemporaneous with Djebel Krechem that belongs to the Segui Formation stratigraphically above the Beglia formation (Mannaï-Tayech, 2009), which includes Bled Douarah. The age of Bled Douarah is not well constrained but generally considered to be late Serravalian-Early Tortonian (12-11 Ma, Geraads,1989; Pickford, 2000). The limit between the two fossiliferous levels in Bled Douarah is supposed to be early late Miocene and marked by the appearance of hipparions (Robinson and Black, 1969) in correlation with the earliest record of equids in Africa in Bou Hanifia (10.5 Ma, Bernor et al., 2010). The presence of Kenyapotamus coryndoni in the upper level allows comparison with levels in the Ngorora, Nakali and Namurungule formations in Kenya dated between 11 and $8.8 \mathrm{Ma}$ (see Boisserie et al., 2010 for review). The localities of the lower level of Bled Douarah must therefore be older than $10.5 \mathrm{Ma}$

Due to the presence of $L$. algeriensis at Bir el Ater 3 this locality must be older than the earliest localities of Bled Douarah where L. anisae (more advanced species of the genus) occurs. Unfortunately, we do not have a lowermost constrained age for the Algerian locality due to the unconformity between the Miocene Nementcha formation and the Eocene continental sequence and the temporal distribution of the found genera, which are not known in Africa prior to 11 Ma. Pickford (2009) proposed a Langhian age for Bir el Ater 2 (ca. $14 \mathrm{Ma}$ ), which is almost contemporaneous with Bir el Ater 3. The Asian origin of the genus Libycosaurus would constrain the age of the dispersal from Asia to Bir el Ater 3. For the moment, two hypotheses have been proposed: 1) Libycosaurus is the sister clade of Merycopotamus (Lihoreau et al., 2006) and thus its origin can be constrained with the earliest occurrence of its sister group, Merycopotamus (13.9 Ma, earliest occurrence of Merycopotamus nanus, Lihoreau et al., 2007), 2) Libycosaurus is included within Merycopotamus clade (Lihoreau et al., 2015) and its earliest occurrence might be younger. This point has to be resolved by new phylogenetic analysis of this clade including $L$. algeriensis which hypodigm clearly needs to be completed by new dental material (premolar and anterior teeth morphology). Depending on which scenario will be retained the new remains of Tetralophodon from Bir el Ater 3 might represent the earliest occurrence of this genus in Africa. This point is therefore critical to date dispersal events of large terrestrial mammals toward Africa during middle Miocene or early Late Miocene.

\section{ACKNOWLEDGMENTS}

We thank S. Jiquel for preparation and cast of the material. We are grateful to Pascal Tassy and one anonymous reviewer for their comments that greatly improved the quality of the manuscript. This is ISE-M publication 2015-117SUD.

\section{BIBLIOGRAPHY}

Alloing-Séguier, L., Lihoreau, F., Boisserie, J.-R., Charruault, A.-L., Orliac, M., Tabuce, R., 2014. Enamel microstructure evolution in anthracotheres (Mammalia, Cetartiodactyla) and new insights on hippopotamoid phylogeny. Zoological Journal of the Linnean Society 171, 668-695.

Arnason, U., Gullberg, A., Gretarsdottir, S., Ursing, B., Janke, A., 2000. The mitochondrial genome of the sperm whale and a new molecular reference for estimating eutherian divergence dates. Journal of Molecular Evolution 50(6), 569-578.

Bergounioux, F.-M., Crouzel, F., 1956. Présence de Tetralophodon longirostris dans le Vindobonien inférieur de Tunisie. Bulletin de la Société Géologique de France 6, 431-443.

Bernor, R. L., Armour-Chelu, M. J., Gilbert, H., Kaiser, T. M., Schulz, E., 2010. Equidae. In: Werdelin, L., Sanders, W. J. (Eds.), Cenozoic Mammals of Africa. University of California Press, Berkeley, Los Angeles, London, pp. 685-721.

Black, C. C, 1972. A new species of Merycopotamus (Artiodactyla : Anthracotheriidae) from the late Miocene of Tunisia. Notes du service Géologique de Tunis 37, 5-37.

Boisserie, J.-R, Lihoreau, F., Orliac, M., Fisher, R. E., Weston, E. M. Ducrocq, S., 2010. Morphology and phylogenetic relationships of the earliest known hippopotamids (Cetartiodactyla, Hippopotamidae, Kenyapotaminae). Zoological Journal of the Linnean Society 158, 325-366.

Bonarelli, G., 1947. Dinosauro fossile del Sahara Cirenaico. Rivista Biologica Colonial Roma 8, 23-33.

Bonis, L. De, Jaeger, J.-J., Coiffait, B., Coiffait P.-E., 1988. Découverte du plus ancien primate Catarrhinien connu dans l'Eocène supérieur d'Afrique du Nord. Comptes Rendus de l'Académie des Sciences, Série 2306 (13), 929-934.

Chow, M., Chang, Y., 1974. Proboscidean fossils of China. Beijing: Institute of Vertebrate Palaeontology and Palaeoanthropology 74 pp.

Coiffait, P.-E., Coiffait, B., Jaeger, J.J., Mabhoubi, M., 1984. Un nouveau gisement à mammifères fossiles d'âge Eocène supérieur sur le versant sud des Nementcha (Algérie orientale) : découverte des plus anciens rongeurs d'Afrique. Comptes rendu de l'Académie des Sciences, Paris 299. 893-898.

Coppens, Y., Maglio, V. J., Madden, C. T., Beden, M., 1978. Proboscidea. In: Maglio, V. J., Cooke H. B. S. (Eds.), 
Evolution of African Mammals. Harvard University Press, Cambridge, pp. 336-367.

Dong,W., 1987. Miocene mammalian fauna of Xiaolongtan, Yunnan Province. Vertebrata Palasiatica 25,116-123.

Douady, C. J., Catzeflis, F., Raman, J., Springer, M. S., Stanhope, M. J., 2003. The Sahara as a vicariant agent, and the role of Miocene climatic events, in the diversification of the mammalian order Macroscellidea (elephant shrews). Proceeding of the National Academy of Sciences, USA 100 (14), 8325-8330.

Ducrocq, S., Coiffait, B., Coiffait P.-E., Mahboubi, M., Jaeger, J.-J. 2001. The miocene Anthracotheriidae (Artiodactyla, Mammalia) from the Nementcha, eastern Algeria. Neues Jahrbuch für Geologie und Paläontologie, Monatshefte 3, $145-156$.

Falconer, H., 1857. On the species of mastodon and elephant occurring in the fossil state of Great Britain. Part I. Mastodon. Quaterly Journal of the Geological Society of London 13, 307-360.

Gaziry, A. W., 1987. 15. Remains of Proboscidea from the early Pliocene of Sahabi, Libya. In: Boaz, N. T., El-Arnauti, A., Gaziry, A. W. (Eds.), Neogene Paleontology and Geology of Sahabi. John Wiley and Sons, New-York, pp. 183-203.

Gentry, A. W., Hooker, J. J., 1988. The phylogeny of the Artiodactyla. In Benton, M. J. (Ed.), The phylogeny and classification of the Tetrapods, volume 2, Mammals. Systematic Association Special Volume 35B, Clarendon Press, Oxford, pp. 235-272.

Geraads, D., 1989. Vertébrés fossiles du Miocène supérieur du Djebel Krechem El Artsouma (Tunisie centrale). Comparaisons stratigraphiques. Geobios 22, 777-801.

Geraads, D., Alemseged, Z., Bellon, H., 2002. The late Miocene mammalian fauna of Chorora, Awash basin, Ethiopia: systematics, biochronology and the ${ }^{40} \mathrm{~K}-{ }^{40} \mathrm{Ar}$ ages of the associated volcanics. Tertiary Research 21, 113-122.

Gray, J. E., 1821. On the natural arrangement of vertebrose animals. London Medical Repository 15, 296-310.

Griffin, D. L., 2002. Aridity and humidity: two aspects of the late Miocene climate of North Africa and the Mediterranean. Palaeogeography, Palaeoclimatology, Palaeoecology 2808, 1-27.

Hautier, L., Mackaye, H. T., Lihoreau, F., Tassy, P., Vignaud, P., Brunet, M., 2009. New material of Anancus kenyensis (Proboscidea, Mammalia) from Toros-Menalla (Late Miocene, Chad): Contribution to the systematics of African anancines. Journal of African Earth Sciences 53 (4-5), 171-176.

Hay, O. P., 1922. Further observations on some extinct elephants. Proceedings of the Biological Society of Washington 35, 97-101.

Hopwood, A. T., 1935. Fossil Proboscidea from China. Palaeontologia Sinica 9 (3), 1-109.

Illiger, C. D., 1811. Prodromus systematis mammalium et avium additis terminis zoographicis uttriusque classis. Salfeld, Berlin.

Kaup, J. J., 1832. Ueber zwei Fragmente eines Unterkiefers von Mastodon angustidens Cuv., nach welchen diese Art in die Gattung Tetracaulodon Godmann gehört. Isis, 25, 628-631.

Leidy, J., 1869. The extinct mammalian fauna of Dakota and Nebraska. Journal of the Philadelphia Academy of Natural Sciences 7, $1-472$.

Lihoreau, F., Barry, J., Blondel, C., Brunet, M., 2004. A new species of Anthracotheriidae, Merycopotamus medioximus nov. sp. from the Late Miocene of the Potwar Plateau, Pakistan. Comptes rendus Palevol, 3, 653-662.

Lihoreau, F., Boisserie, J.-R., Viriot, L., Coppens, Y., Likius, A., Mackaye, H. T., Tafforeau, P., Vignaud, P., Brunet, M., 2006. Anthracothere dental anatomy reveals a late Miocene Chado-Libyan bioprovince. Proceedings of the National Academy of Sciences, USA, 103, 8763-8767.

Lihoreau, F., Ducrocq, S., 2007. Family Anthracotheriidae. in Prothero, D. R., Foss, S. E., (eds), The Evolution of Artiodactyls. Johns Hopkins University Press, Baltimore, pp. 89-105.

Lihoreau, F., Barry, J., Blondel, C., Chaimanee, Y., Jaeger, J-J., Brunet, M., 2007. Anatomical revision of the genus Merycopotamus [Artiodactyla; Anthracotheriidae]: its significance on late Miocene mammal dispersions in Asia. Palaeontology 50 (2), 503-524.

Lihoreau, F., Boisserie, J. -R., Blondel, C., Jacques, L., Likius, A., Mackaye, H. T., Vignaud, P. Brunet, M., 2014. Description and palaeobiology of a new species of Libycosaurus (Cetartiodactyla, Anthracotheriidae) from the Late Miocene of Toros-Menalla, northern Chad. Journal of Systematic Palaeontology 12 (7), 761-798.

Lihoreau, F., Boisserie, J.-R., Manthi, F. K., Ducrocq, S., 2015. Hippos stem from the longest sequence of terrestrial cetartiodactyl evolution in Africa. Nature Communications, 1-8. 6:6264, doi: $10.1038 /$ ncomms 7264 .

Lydekker, R., 1877. Notices of new and other Vertebrata from Indian Tertiary and Secondary Rocks. Records of the Geological Survey of India 10, 1-3043.

Lydekker, R., 1886. Addenda to synopsis of Siwalik and Narbada Mammalia. Memoirs of the Geological Survey of India Palaeontologia Indica 3, 11-24.

Maarel, F. H. van der, 1932. Contributions to the knowledge of the fossil mammalian fauna of Java. Wetenschappelijke Mededeelingen Dienst van de Mijnbouw in Nederlandsch Oost Indie 15, 1-208.

Madden, C., 1977. Tetralophodon (Proboscidea, Gomphotheriidae) from the Subsaharan Africa. Revue de Zoologie Africaine 91, 152-160.

Madden, C. T., 1982. Primitive Stegotetrabelodon from latest Miocene of Subsaharan Africa (Proboscidea, Gomphoteriidae). Revue de Zoologie Africaine 96, 782-796.

Mahboubi, M., Tabuce, R., Mebrouk, F., Coiffait, B., Coiffait P.-E., Jaeger, J.-J., 2003. L'Eocène continental à vertébrés de la bordure sud des monts de Nementcha (Atlas Saharien oriental, Algérie) : précisions stratigraphiques et implications paléobiogéographiques. Bulletin du Service Géologique de l'Algérie 14 (1), 27-35.

Mannaï-Tayech, B., Otero, O., 2005. Un nouveau gisement miocène à ichthyofaune au sud de la chaîne des Chotts (Tunisie méridionale). Paléoenvironnement et paléobiogéographie. C. R. Palevol 4, 405-412.

Mannaï-Tayech, B., 2006. Miocene silicoclastic series from North-Eastern to South-Western of Tunisia: standpoint. Geobios 39, 71-84.

Mannaï-Tayech, B., 2009. The lithostratigraphy of Miocene series from Tunisia, revisited. Journal of African Earth Sciences 54, 53-61.

Montgelard, C., Catzeflis, F., Douzery, E., 1997. Phylogenetic relationships of artiodactyls and cetaceans as deduced from the comparison of cytochrome $b$ and 12s rRNA mitochondrial sequences. Molecular Biology and Evolution 14: 550-532.

Nakaya, H., Pickford, M., Nakano, Y., Ishida, H., 1984. The Late Miocene large mammal fauna from the Namurungule Formation, Samburu Hills, Northern Kenya. African study monographs, supplementary issue 2, 87-131.

Nakaya, H., Pickford, M., Yasui, K., Nakano, Y., 1987. Additional Large Mammalian Fauna from the Namurungule Formation, Samburu Hills, Northern Kenya. African study monographs, supplementary issue 5, 79-129.

Osborn, H. F., 1936. Proboscidea. A monograph of the discovery, evolution, migration and distinction of the mastodonts and elephants of the world. The American Museum Press, New York, pp. 1-802.

Pickford, M., 1978. Stratigraphy and mammalian palaeontology of the late Miocene Lukeino Formation, Kenya. In: Bishop, W. W. (Ed.), Geological background to fossil man. Scottish Academy Press, Edinburgh, pp. 264-278.

Pickford, M., 2000. Crocodiles from the Beglia Formation, Middle/ late Miocene boundary, Tunisia, and their significance for Saharan palaeoclimatology. Annales de Paléontologie 86 (1), 59-67.

Pickford, M., 2006. Sexual and individual morphometric variation in Libycosaurus (Mammalia, anthracotheriidae) from the Maghreb and Libya. Geobios 39, 267-310. 
Pickford, M., 2009. Metric variation in Afromeryx and Libycosaurus (Anthracotheriidae: Mammalia) and its utility for biochronology. Revista Española de paleontología 24 (2), 107-120.

Qi, G., Dong, W., Zheng, L., Zhao, L., Gao, F., Yue, L., Zhang, Y., 2006. Taxonomy, age and environment status of the Yuanmou hominoids. Chinese Science Bulletin 51, 704-712.

Robinson, P., Black, C. C., 1969. Note préliminaire sur les vertébrés fossiles du Vindobonien (formation Béglia) du Bled Douarah, gouvernorat de Gafsa, Tunisie. Notes du service Géologique de Tunis 31, 67-70.

Robinson, P., Black, C. C., 1974. Vertebrate faunas from the Neogene of Tunisia. Annals of the Geological Survey of Egypt 4, 319-332.

Saegusa, H., Nakaya, H., Kunimatsu, Y., Nakatsukasa, M., Tsujikawa, H., Sawada, Y., Saneyoshi, M., Sakai, T., 2014. Earliest elephantid remains from the Late Miocene locality, Nakali, Kenya. Scientific Annals, School of Geology, Aristotle University of Thessaloniki, Greece $\mathrm{VI}^{\text {th }}$ International Conference on Mammoths and their Relatives, Grevena Siatista, special volume 102, 175.

Sanders, W. J., 1997. Fossil proboscidea from the Wembere-Manonga formation, Manonga valley, Tanzania. In: Harrison, T. (Ed.), Neogene Paleontology of the Manonga Valley, Tanzania, Vol. 14 of Topics in Geobiology. Plenum Press, New-York, pp. 265-310.

Sanders, W. J., Gheerbrant, E., Harris, J. M., Saegusa, H., Delmer, C., 2010. Proboscidea. In: Werdelin, L., Sanders, W. J. (Eds.), Cenozoic Mammals of Africa. University of California Press, Berkeley, Los Angeles, London, pp. 161-251.

Sarwar, M., 1977. Taxonomy and distribution of the Siwalik Proboscidea. Bulletin of the department of Zoology of the University of Punjab 10, 1-172.

Schlessinger, G., 1917. Die mastodonten des K. K. naturhistorischen Hofmuseums. Denkschriften Kaiserlich Königlichen Naturhistorische Hofmuseum 1, 1-230.

Schlessinger, G., 1922. Die mastodonten der Budapester Sammlungen. Geologica Hungarica 2, 1-284.

Scott, W. B. 1940. Part IV: Artiodactyla. In Scott, W. B., Jepsen, G. L. (eds.), The mammalian fauna of the White River Oligocene. Transactions of the American Philosophical Society 28, pp. 363-746.

Shoshani, J., Tassy, P., 1996. The Proboscidea. Evolution and palaeoecology of elephants and their relatives. Oxford University Press, Oxford, 472p.
Suwa, G., Kono, R. T., Katoh, S., Asfaw, B., Beyen, Y., 2007. A new species of great ape from the late Miocene epoch in Ethiopia. Nature 448, 921-924.

Tassy, P., 1983. Les Elephantoidea miocènes du plateau Potwar. Groupe de Siwalik, Pakistan. IIème partie: choerolophodontes et gomphothères. Annales de Paléontologie 69, 235-297.

Tassy, P., 1988. The classification of Proboscidea: how many cladistic classifications? Cladistics 4, 43-57.

Tassy, P., 1986. Nouveau Elephantoidea (Mammalia) dans le Miocène du Kenya, essai de réévaluation systématique. Cahiers de Paléontologie (Travaux de Paléontologie Est-Africaine). CNRS, Paris.

Tassy, P., 1994. Les proboscidiens (Mammalia) fossiles du rift occidental, Ouganda. In: Senut, B., Pickford, M. (Eds.), Geology and Palaeobiology of the Albertine Rift Valley, Uganda-Zaire. Vol. II: Palaeobiology. CIFEG, Orléans, pp. 217-257.

Tassy, P., 2003. Elephantoidea from Lothagam. In: Leakey, M. G., Harris, J. (Eds.), The dawn of humanity in Eastern Africa. Columbia University Press, New-York, pp. 331-352.

Tiercelin, J-J., Michaux, J., Bandet, Y., 1979. Le Miocène supérieur du Sud de la dépression de l'Afar, Ethiopie : sédiments, faunes, âges isotopiques. Bulletin de la Société Géologique de France $21,255-258$.

Tobien, H., 1978. On the evolution of Mastodonts (Proboscidea, Mammalia). Part 2: the bunodont tetralophodont groups. Geologisches Jahrbuch Hessen 106, 159-208.

Tobien, H., Chen, G., Li, Y., 1988. Mastodonts (Proboscidea, Mammalia) from the Late Neogene and Early Pleistocene of the People's Republic of China. Mainzer Geowissenschaften Mitteilung 17, 95-220.

Tsujikawa, H., 2005. The updated late Miocene large mammal fauna from Samburu Hills, Northern Kenya. African study monographs, supplementary issue $32,1-50$.

Werdelin, L., 2010. Chronology of Neogene Mammal localities. In: Werdelin, L., Sanders, W. J. (Eds.), Cenozoic Mammals of Africa. University of California Press, Berkeley, Los Angeles, London, pp. 27-43.

Zouhri, S., Geraad, D., El Boughabi, S., El Harfi, A., 2013. Discovery of an Upper Miocene Vertebrate fauna near Tizi N'Tadderht, Skoura, Ouarzazate Basin (Central High Atlas, Morocco). Comptes Rendus Palevol 11, 455-461. 